\title{
The Effect of Corporate Governance on Earnings Management through Accounting Conservatism
}

\author{
Agung Nurmansyah ${ }^{1}$, Widji Astuti ${ }^{2}$, Prihat Assih ${ }^{3}$ \\ ${ }^{1}$ Doctoral Program in Economic Science, University of Merdeka Malang, Indonesia \\ ${ }^{2.3}$ University of Merdeka Malang, \\ Indonesia
}

\begin{abstract}
This study aimed to analyze the influence of corporate governance on accounting conservatism, analyze the impact of corporate governance on earnings management, analyze the effect of accounting conservatism and analyze the impact of corporate governance on earnings management through accounting conservatism. The sample in this study as many as 15 banks. Data were analyzed using path analysis. The analysis showed that corporate governance affect accounting conservatism. Corporate governance effect on earnings management. Accounting conservatism effect on earnings management. Corporate governance effect on earnings management through accounting conservatism.
\end{abstract}

Keywords: Corporate governance, Accounting Conservatism, Earnings Management.

\section{INTRODUCTION}

The banking industry in 2016 still plays an important role in the financial system in Indonesia with a market share of 60 percent. Banking is an institution that plays a role in financing the economy in Indonesia. Under Law No. 10 In 1998, the bank is a business entity that collects funds from the public in the form of deposits and distribute it to the public in the form of credit and other forms with the aim of improving the living standards of the people. Banking intermediation has a function that is raising funds from the public and then transferring financial assets to the unit in the form of credit. Characteristics of the banking industry is different from the manufacturing industry and the service industry, since most of the banks' capital (over 80 percent) came from customers, financial markets and funds outside the company.

Earnings management arise due to a conflict of interest between the management (agent) by the owner (principal). This arises because each party seeks to achieve and maintain the desired level of prosperity. Conflict of interest occurs because of the separation of ownership with the management of the company (agency conflict). The owners give authority and freedom to the manager to take care of the company, but the owners (shareholders) give particular to managers. So managers earning management because of the pressure to report a stable financial position annually to shareholders, creditors and the other parties who have an interest, so that managers take management action's financial statements [1]. Manajenen action to prevent any company can profit corporate governance implementation. Corporate governance is the set of rules that govern the relationship between shareholders and management company. Corporate governance required to implement a way or method called good corporate governance mechanism. Good corporate governance mechanisms used are the board of directors, audit committee, managerial ownership and institutional ownership. The concept of good corporate governance is proposed in order to achieve a more transparent corporate management for all users of financial statements. Corporate governance required to implement a way or method called good corporate governance mechanism. Good corporate governance mechanisms used are the board of directors, audit committee, managerial ownership and institutional ownership. The concept of good corporate governance is proposed in order to achieve a more transparent corporate management for all users of financial statements. Corporate governance required to implement a way or method called good corporate governance mechanism. Good corporate governance mechanisms used are the board of directors, audit committee, managerial ownership and institutional ownership. The concept of good corporate governance is proposed in order to achieve a more transparent corporate management for all users of financial statements.

Corporate governance is used to ensure that all activities of the company including accounting method the company has been run optimally. Implementation of corporate governance made by all parties within the company, especially the top management to take action menyusunan conservative in the company's financial statements. Accounting conservatism is one method of accounting recognition are believed to be able to anticipate uncertainty (reducing the risk) that occur in each company [2]. The principle of conservatism is the precautionary principle to an uncertain circumstances to avoid the excessive optimism of 
the management and owners of the company. In the company's accounting conservatism applied in different levels. One of the factors that determine the level of conservatism in financial reporting of a company is the commitment of management and the company's internal parties in providing information that is transparent, accurate and not misleading for investors. Research Leventis et al., stated that commercial banks are registered in the United States with good corporate governance, will conduct financial reporting conservatism compared with those banks that are less good governance [3].

Implementation of accounting conservatism in financial reporting can minimize the chance of managers to manipulate earnings and reduce conflicts of interest. Conservatism has a relationship with earnings management, conservatism can restrict the actions that managers opportunistically manage earnings and utilize the position as a manager who has more information from the parties outside the company. Research conducted Lafond and Watts states that the higher role of accounting conservatism, then the opportunity for managers to perform manipulation and overstatement of financial statements can be minimized so that the cash flow and the company's value can be improved [4].

This study aimed to analyze the influence of corporate governance on accounting conservatism, analyze the impact of corporate governance on earnings management, analyze the effect of accounting conservatism and analyze the impact of corporate governance on earnings management through accounting conservatism.

\section{LITERATURE REVIEW}

\subsection{Corporate Governance}

Corporate governancebasically a matter of controlling the behavior of top executives of the company to protect the interests of company owners (shareholders). Corporate governance problem occurs because the separation between ownership with control in the company. These problems can be traced from the development agency theory that explains the parties involved in the company (managers, company owners and creditors) will behave in accordance with their respective his interest or have different interests.

According to Iskander and Chamlou under the supervision of corporate governance mechanisms are divided into two groups: internal and external mechanisms of internal mechanisms [5]. External mechanism is a way to influence the company in addition to using an internal mechanism, such as control of the company and market control. Internal mechanism is a way to control the company by using the structure and internal processes such as the general meeting of shareholders (AGM), the composition of the board of directors, the composition of the board of commissioners and board of directors meeting.

\subsection{Accounting Conservatism}

Watts defines conservatism as the principle of prudence in financial reporting that companies are not in a hurry in recognizing and measuring assets and profits, and immediately recognize the loss and debt that is likely to occur [6]. The application of this principle resulted in selection of accounting methods directed to methods reported lower earnings or assets, and report higher debt. In this concept, the load must be immediately recognized than income, so that net income looks low. Furthermore, conservatism will cause financial reporting pessimistic, it will reduce the optimism of the report. According Martani and Dini, pessimism is needed to neutralize the excessive optimism manager [7].

As with the Basu which defines conservatism as the practice of reducing net earnings (net assets shrink) in response to bad news (bad news) but does not increase profits when responding to the good news (good news) [8]. While Givoly and Hyan, defines conservatism as the initial recognition of the cost and loss and delay the recognition of revenue and profit recognition [9].

\subsection{Earnings Management}

Earnings management is one of the factors that can reduce the credibility of financial statements are primarily corporate earnings. Add to earnings management bias in the financial statements and may make wrong decisions because of modified financial report. Earnings management is often done by company policy to manipulate earnings from operating results. Earnings management is done by selecting accounting methods that can raise or lower profits. According to Scott earnings management is accounting policies applied by the manager of the existing accounting standards and are naturally able to maximize the utility or the market value of the company [10].

\subsection{Hypothesis}

H1 : Corporate governance effect on accounting conservatism

H2 : Corporate governance effect on earnings management

H3 : Conservatism accounting effect on earnings management

H4 : Corporate governance effect on earnings management through accounting conservatism 


\section{RESEARCH METHODS}

\subsection{Research design}

This research included in this type of explanatory (explanatory research) aims to obtain a complete picture and complete and clarify or explain a phenomenon, explain relationships, examines the effect (causality) between variables, evaluating, and knowing the difference or ratio. Pattern effect will be revealed in this study is a direct and indirect influence of corporate governence to earnings management through accounting conservatism.

\subsection{Population and Sample}

The population used in this study are all banking companies listed in Indonesia Stock Exchange (BEI) from 2013 to 2017 as many as 45 companies. Sampling was done by using purposive sampling method, namely the determination of the sample on the basis of the characteristics and suitability of certain criteria. In this study, the sample selection was based on the following criteria:

1) Banking companies listed in the Stock Exchange (Stock Exchange Indonesia) in 2013-2017.

2) Bank qualifies book 3 and book 4 .

3) Perusaahaan banking listings on the observation period.

4) Banking company publishes audited annual report ended on December 31 during the observation period.

5) The Company has extensive information on corporate governance, competition, quality audit, accounting conservatism and earnings management.

6) The Company presents financial statements in the rupiah.

7) Companies that do not undergo delisting

The Company has data on the composition of the board of directors, audit committee, the level of competition, data relating to public accounting firm that audits the company, the value of shares of the company and the data associated with the variables to be studied in the annual financial statements of the company that was published in from 2013 to 2017.

\subsection{Operational Definition of Variables}

Operational variables are used to clarify the operation of some of the concepts and terms that are discussed in this study design, given the constraints in order to avoid misinterpretation:

a. Corporate governance (X1)

Corporate governanceis a system that regulates and controls the companies that create added value for all stakeholders. Corporate governance is proxied independent board. Commissioner is an independent implementation of monitoring functions in order to create good corporate govevernance company. Measurement variables independent board with the proportion of independent board compared to the overall commissioners [11].

The proportion of independent commissioners $(\mathrm{X} 1)=\frac{\text { Independent Commisioner }}{\text { Total commisioners }} \times 100 \%$

The Board of Commissioners is one of the control functions are contained in a company. Bank Indonesia Regulation No. 8/4 / PBI / 2006, the proportion of independent board at least $50 \%$ of the number of commissioners. The proportion of the commissioners can make an effective contribution to the outcome of the process of preparing financial statements is qualified or the possibility to avoid fraudulent financial statements.

b. Accounting Conservatism (Y1)

Accounting Conservatism is the act (precautionary) management slower recognize revenue or profits, resulting in profit and revenue figures tend to be lower. In this study, conservatism will be proxied by the net asset measures. One model is a proxy measurement of measurement used by Beaver and Ryan, that uses a market-to-book ratio that reflects the market value relative to the book value of the company [12]. Ratios are worth more than 1, indicating the application of conservative accounting for companies record the value of the company is lower than its market value. The equation to measure accounting conservatism.

$$
\begin{array}{ll}
\text { Market-to-book ratio }(\mathrm{Y} 1)= & \frac{\text { The market price per share }}{\text { Book value per share }} \\
\text { Book value per share } & =\frac{\text { Total equity }}{\text { Number of shares outstanding }}
\end{array}
$$

c. Earnings management (Y2)

Earnings management is a way of presenting earnings adjusted to the desired destination by the manager. Measurement of earnings management using Eckel Index. Gain Flattening action tested by Eckel index (1981). Eckel using the coefficient of variation $(\mathrm{CV})$ of variables and variable income net sales. Gain Flattening Index is calculated as follows: 
Eckel Index $(\mathrm{Y} 2)=\frac{\mathrm{CV} \Delta \mathrm{I}}{\mathrm{CV} \Delta \mathrm{S}}$

Where:

$\Delta \mathrm{I}$ : Change in profit in one period

$\Delta \mathrm{S}$ : Change in sales in one period

$\mathrm{CV}$ : coefficient of variation of variables, standard deviation divided by the expected value.

Companies that perform income smoothing or that do not perform income smoothing can be detected through Eckel index to see if the value Eckel index greater than 1 (one), the company does not carry out smoothing earnings, but if Eckel index is smaller than 1 (one), then the company the income smoothing.

\subsection{Data analysis technique}

Data analysis techniques used in this research are descriptive statistics, classical assumption test, and path analysis. Analysis lane or path analysis aims to examine the direct or indirect influence of the independent variables on the dependent variable. In fact the causal relationship can only occur one or more independent variables affect directly or indirectly dependent variable.

\section{RESULTS AND DISCUSSION}

\subsection{Descriptive statistics}

Descriptive statistical analysis is used to provide a picture or description of the study variables. Descriptive statistical analysis in this study on the value of corporate governance, accounting conservatism and earnings management in the Indonesian banking industry listed on the Stock Exchange in the year 2013-2017. Measurements used in the descriptive analysis are the minimum, maximum, mean and standard deviation. Mean is used to determine the average value of the data concerned. Standard deviation is used to determine how much of the data in question varies from the average. The maximum value is used to determine the greatest value of the data concerned. The minimum value is used to determine the smallest value of the data concerned.

Table 1 Descriptive Analysis

\begin{tabular}{|l|r|r|r|r|r|}
\hline & $\mathrm{N}$ & \multicolumn{1}{|c|}{ Min } & Max & mean & \multicolumn{1}{c|}{ Std. deviation } \\
\hline Corporate Governance & 75 & 0.4 & 0.8 & 0.56 & 0.092 \\
\hline Accounting conservatism & 75 & 0.08 & 4.41 & 1.45 & 0.92 \\
\hline Earnings management & 75 & -1994.56 & 1562.84 & 0.25 & 298.19 \\
\hline
\end{tabular}

Source: Data are processed, 2019.

Corporate governance an assessment of the implementation of the principles of good corporate governance, corporate governance is proxied by the proportion between the number of independent directors with the total number of commissioners. Independent board has the function as the supervision and coordination of the company, ensuring the well-executed corporate strategy, control managers in corporate management, and require effective accountability. From table 1 shows the number of samples $(\mathrm{N})$ of 75 . Based on the calculation of descriptive statistics can be seen that the banking industry is listed on the Stock Exchange (Stock Exchange Indonesia) in the year 2013 to 2017 has a value of proportion to the number of independent board is the lowest 0.4 while the value of the proportion of independent board highest number was 0.8 , the average number of commissioners proportion of banks is 0.56 and standard deviation 0, 092.

Conservatism as the principle of prudence in financial reporting that companies are not in a hurry in recognizing and measuring assets and profits, and immediately recognize the loss and debt that is likely to occur. From table 3 accounting conservatism sample number $(\mathrm{N})$ of 75 . Based on the calculation of descriptive statistics can be seen that the banking industry is listed on the Stock Exchange (Stock Exchange Indonesia) in the year 2013 to 2017 has the lowest value accounting conservatism is 0.08 while the highest value is 4.41 , standard deviation0.92 and average accounting conservatism in the banking industry is 1.45 .

Earnings management is management policy that is often done by companies to change the company's profit in accordance with company objectives. Earnings management is done by selecting accounting methods that can raise or lower profits. To determine the level of earnings management in the banking industry can be seen in Table 3, the number of samples used to find earnings management $(\mathrm{N})$ of 75 . Based on the calculation of descriptive statistics can be seen that the banking industry listed on the Stock Exchange had the lowest earnings management value is -1994 , 56 while the highest value was 1562.84, 298.19 and a standard deviation of the average value of earnings management in the banking industry was 0.247 , 


\subsection{The results of path analysis}

Analysis of the data used in this research is the analysis of lane or path analysis by using computer program SPSS version 24. The chosen path analysis for this analysis is used to analyze the pattern of relationships between variables. In this study the model there are intervening variables, namely the effectiveness of accounting conservatism that mediate the relationship between corporate governance, audit quality and competition with earnings management.

Table 2 Hypothesis Testing Results Direct and Indirect Effects of inter Variable Research

\begin{tabular}{|c|c|c|c|c|c|c|}
\hline $\begin{array}{c}\text { Exogenous } \\
\text { variables }\end{array}$ & $\begin{array}{c}\text { Intervening } \\
\text { variable }\end{array}$ & $\begin{array}{c}\text { Endogenous } \\
\text { variables }\end{array}$ & Direct Effect & $P$ value & Indirect Effext & Total Effect \\
\hline $\begin{array}{l}\text { Corporate } \\
\text { governance }\end{array}$ & $\begin{array}{l}\text { accounting } \\
\text { Conservatism }\end{array}$ & - & 0.332 & 0.002 & - & - \\
\hline $\begin{array}{l}\text { Corporate } \\
\text { governance }\end{array}$ & - & $\begin{array}{l}\text { Earnings } \\
\text { management }\end{array}$ & 0.466 & 0.002 & - & - \\
\hline- & $\begin{array}{l}\text { accounting } \\
\text { Conservatism }\end{array}$ & $\begin{array}{l}\text { Earnings } \\
\text { management }\end{array}$ & 0.391 & 0.046 & - & - \\
\hline $\begin{array}{l}\text { Corporate } \\
\text { governance }\end{array}$ & $\begin{array}{l}\text { accounting } \\
\text { Conservatism }\end{array}$ & $\begin{array}{l}\text { Earnings } \\
\text { management }\end{array}$ & 0.466 & 0.002 & 0.129 & 0.595 \\
\hline
\end{tabular}

According to the table 2 can be explained as follows:Corporate Governacepositive and significant effect on accounting conservatism, so the stronger corporate governance of banking in Indonesia it will be more effective accounting conservatism. From Table 2, it appears that corporate Governace positive and significant effect on accounting conservatism is indicated with $\mathrm{p}$ value of 0.002 qualified ie> 0.05 . Thus the first hypothesis in this study is proven and significant.

Corporate Governacea significant negative effect on earnings management, so that the stronger corporate governance of banking in Indonesia will lower earnings management. From Table 2, it appears that corporate Governace and significant impact negatively on earnings management indicated with $\mathrm{p}$ value of 0.002 qualified ie $<0.05$. Thus the second hypothesis in this study is proven and significant.

Accounting Conservatism positive and significant effect on earnings management accounting conservatism and the more powerful the more powerful earnings management. From Table 2, it appears that accounting conservatism positive and significant effect on earnings management with $\mathrm{p}$ value of 0.046 indicated that qualifies is $>0.05$. Thus the third hypothesis in this study is proven and significant.

Corporate Governaceindirect effect on earnings management through conservatism. From table 2 it can be seen the indirect effect of corporate governance on earnings management through accounting conservatism amounted to $0.129(0.332 \mathrm{x}$ 0.391). The direct effect of corporate governance on accounting conservatism is 0.466 . The total effect of $0.595(0.129+0.466)$. The results prove that the direct effect <influence total $(0.466<0.595)$, so that the corporate governance effect on earnings management through accounting conservatism. Thus the hypothesis 4 in this study, corporate Governace indirect effect on earnings management through conservatism.

\subsection{Discussion}

\section{a. Influence of Corporate Governance on Accounting Conservatism}

Corporate Governacesignificant and positive impact on accounting conservatism, this means that the greater the effect of the number of independent board then increasing the level of accounting conservatism. The results of this study are supported by research Son et al, (2015) stated there is a positive and significant relationship between the proportion of independent board with accounting conservatism. The Government through the Bank Indonesia regulates the application of good corporate governance in the banking industry by issuing a Bank Indonesia regulation No. 8/4 / PBI / 2006 regarding the implementation of good corporate governance for commercial banks, as well as the FSA regulations NO. 55 / FSA / 2016 concerning the number of commissioners is at least 3 people and 50\% should be composed of independent board. Implementation of good corporate governance to enhance the bank's image,

Perbankkan good corporate governance should be reported in the annual reports of banks and can be monitored by the public and the government. Implementation of good corporate governance self assessment (Bank Indonesia Regulation No. 8/4 / PBI / 2006) commercial banks are supervised by the supervisor Bank Indonesia will be a decisive part of the bank. Where Bank Indonesia requires all commercial banks to submit reports every year of good corporate governance and the public can access the report so that the public can judge the bank. So that the bank chose a conservative action to enhance the corporate image and retain customers. 


\section{b. Effect of accounting conservatism on Earnings Management}

Corporate governancea significant and negative effect on earnings management, this means that the greater the effect of the number of independent board will decrease the level of earnings management. The results of this study are supported by research Chtourou stated that corporate governance can limit earnings management practices. In summary, the results of the study found evidence that the effectiveness of the board of directors and audit committee restrict earnings management practices [13]. Good corporate governance mechanisms through the presence on the board of an independent party capable of reducing earnings management action that occurred. Independent commissioner is a member of board of directors who are not affiliated with management, other board members and controlling shareholders, as well as free business relationship or other relationship which could affect its ability to act independently or act solely in the interest of the company. Independent commissioner to oversee the decision of management to use their judgment in making financial reporting and transaction procedures, which aim to affect contractual and mislead other parties in making decisions. There are three objectives to be achieved by a manager in relation to the earnings management. The target is to maximize personal welfare (manager), reducing political costs and minimize the financial costs. From this goal can describe aspects of personal benefit to the welfare of the owners. Independent commissioner to oversee the decision of management to use their judgment in making financial reporting and transaction procedures, which aim to affect contractual and mislead other parties in making decisions. There are three objectives to be achieved by a manager in relation to the earnings management. The target is to maximize personal welfare (manager), reducing political costs and minimize the financial costs. From this goal can describe aspects of personal benefit to the welfare of the owners. Independent commissioner to oversee the decision of management to use their judgment in making financial reporting and transaction procedures, which aim to affect contractual and mislead other parties in making decisions. There are three objectives to be achieved by a manager in relation to the earnings management. The target is to maximize personal welfare (manager), reducing political costs and minimize the financial costs. From this goal can describe aspects of personal benefit to the welfare of the owners. The target is to maximize personal welfare (manager), reducing political costs and minimize the financial costs. From this goal can describe aspects of personal benefit to the welfare of the owners. The target is to maximize personal welfare (manager), reducing political costs and minimize the financial costs. From this goal can describe aspects of personal benefit to the welfare of the owners.

\section{c. Accounting Conservatism influence on Earnings Management}

The results showed a significant effect of accounting conservatism and positive, if the level of accounting conservatism increasing the earnings management will increase. This means that the greater influence the level of accounting conservatism will increase the level of earnings management by the company by management. This study was supported by research Ruwanti states that accounting conservatism positive effect on earnings management [14]. If companies are increasingly conservative (if there are conditions that have a possibility of causing damage, costs or debt incurred shall be immediately recognized and if there are conditions that the possibility of generating profits, income, or assets that arise should not be immediately recognized,

\section{d. Influence of Corporate Governance on Earnings Management through Accounting Conservatism}

Corporate governanceindirect effect on earnings management through conservatism. The indirect effect of corporate governance on earnings management through accounting conservatism is larger than the direct effect of corporate governance on earnings management. The influence of corporate governance on earnings management through accounting conservatism, caused banks to run its operations are always closely supervised by the FSA, the media and the public so that the bank safer implement conservative policies. One conservative policy is to decrease the level of corporate profits to improve the bank's image, protect stakeholder interests and to improve compliance with the legislation. These conservative measures,

\section{CONCLUSIONS AND SUGGESTIONS}

\subsection{Conclusion}

1) Corporate Governace positive and significant effect on accounting conservatism, so the stronger corporate governance of banking in Indonesia will be more effective accounting conservatism. This finding is supported by research studies Son et al, (2015) stated there is a positive and significant relationship between the proportion of independent board with accounting conservatism. The Government through the Bank Indonesia began to organize the implementation of good corporate governance in the banking industry by issuing a Bank Indonesia regulation No. 8/4 / PBI / 2006 regarding the implementation of good corporate governance for commercial banks, as well as the FSA regulations NO. 55 / FSA / 2016 concerning the number of commissioners is at least 3 people and 50\% should be composed of independent board. Implementation of good corporate governance to enhance the bank's image, protecting stakeholder interests and improve compliance with laws and regulations so that the application of corporate governance can reduce the risk of bank management, which in turn increases the accounting conservatism. Where Bank Indonesia requires all commercial banks to submit reports every good corporate governance and the public can access the report so that the public can judge the bank. So that the bank chose a conservative action to enhance the corporate image and retain customers. Where Bank Indonesia requires all commercial banks to submit 
reports every good corporate governance and the public can access the report so that the public can judge the bank. So that the bank chose a conservative action to enhance the corporate image and retain customers. Where Bank Indonesia requires all commercial banks to submit reports every good corporate governance and the public can access the report so that the public can judge the bank. So that the bank chose a conservative action to enhance the corporate image and retain customers.

2) Corporate governance take effect significantand the negative to earnings management, this means that the greater the effect of the number of independent board will decrease the level of earnings management. Good corporate governance mechanisms through the presence on the board of an independent party capable of reducing earnings management action that occurred.

3) Accounting conservatism positive and significant effect on earnings management that accounting conservatism is getting stronger the more effective earnings management. This finding is supported by research Ruwanti is a positive effect of accounting conservatism on earnings management [14]. If companies are increasingly conservative (if there are conditions that have a possibility of causing damage, costs or debt incurred shall be immediately recognized and if there are conditions that the possibility of generating profits, income, or assets that arise should not be immediately recognized,

4) Accounting Conservatism mediate influence corporate governance effect on earnings management corporate governance Effect on earnings management through accounting conservatism, caused banks to run its operations are always closely supervised by the FSA, the media and the public so that the bank safer implement conservative policies.

\subsection{Suggestions}

1) For companies are expected to pay more attention to the proportion of independent national commissioners were adequate to control the running of the company in order to avoid earnings management practices and present financial report transaparan.

2) For investors expected with this study can add insight and be more cautious in investing in the company desired.

3) For subsequent researchers suggested adds another variable that would prove the existence of earnings management practices in manufacturing firms such as quality audits and company size.

\section{REFERENCES}

1. Geiger, M., \& Van Der Laan Smith, J. 2010. The Effect of Institutional and Cultural Factors on the Perceptions of Earnings Management. Journal of International Accounting Research, 9(2), 21-43.

2. Fitriani, S. 2014. Pengaruh Mekanisme Good Corporate Governance Terhadap Konservatisme Akuntansi. Jurnal Fakultas Ekonomi dan Bisnis, 1-15.

3. Leventis, S., Dimitropoulos, P., \& Owusu-Ansah, S. 2013. Corporate Governance and Accounting Conservatism: Evidence from the Banking Industry. Corporate Governance. An International Review, 21(3), 264-286.

4. LaFond, R., \& Watts, R. L. 2008. The Information Role of Conservatism. The Accounting Review, 83(2), 447-478.

5. Iskander, M. R., \& Chamlou, N. 2000. Corporate Governance: A Framework for Implementation. World Bank Publications.

6. Watts, R. L. 2003. Conservatism in Accounting part II: Evidence and Research Opportunities. Accounting Horizons, 17(4), 287-301.

7. Martani, D., \& Dini, N. 2010. The Influence of Operating Cash Flow and Investment Cash Flow to the Accounting Conservatism Measurement. Chinese Business Review, 9(6), 1.

8. Basu, S. 1997. The Conservatism Principle and the Asymmetric Timeliness of Earnings1. Journal of Accounting and Economics, 24(1), 3-37.

9. Givoly, D., \& Hayn, C. 2000. The Changing Time-Series Properties of Earnings, Cash Flows and Accruals: Has Financial Reporting Become More Conservative? Journal of Accounting and Economics, 29(3), 287-320.

10. Scott, R. William. 2015. Financial Accounting Theory 7nd Edition. Prentice-Hall, New Jersey.

11. Hastuti, Y. W., \& Achmad, T. 2011. Pengaruh Mekanisme Corporate Governance Secara Internal dan Eksternal Terhadap Kinerja Keuangan: Studi Kasus di Bank yang Terdaftar di BEI 2006-2009 (Doctoral dissertation, Universitas Diponegoro).

12. Beaver, W., Eger, C., Ryan, S., \& Wolfson, M. 1989. Financial Reporting, Supplemental Disclosures, and Bank Share Prices. Journal of Accounting Research, 157-178.

13. Chtourou. 2001. Corporate Governance and Earning Management. http://www.ssrn.com.

14. Ruwanti, Sri. 2016. Pengaruh Konservatisme Akuntansi Pada Manajemen Laba. JEMI, Vol.6. No.1. 